\title{
In situ surface-doped PtNiCoRh nanocrystals promote electrooxidation of $\mathbf{C}_{1}$ fuels
}

\author{
Wei Wang ${ }^{13 \dagger}$, Xuejiao Chen ${ }^{1 \dagger}$, Jinyu $\mathrm{Ye}^{2}$, Yuhui Zhang ${ }^{1}$, Yanchen Han ${ }^{1}$, Xiaowei Chen ${ }^{1}$, \\ Kai Liu ${ }^{1}$ and Shuifen $\mathrm{Xie}^{1^{*}}$
}

\begin{abstract}
Heteroatom-doped Pt-based nanocrystals have generated considerable interest and hold great prospects in heterocatalysis. However, engineering the superficial atomic configurations of these nanocrystals via in situ surface doping remains exceedingly challenging. Herein, we propose a onepot, in situ surface doping chemical synthesis protocol to prepare quatermetallic PtNiCoRh dendritic nanocrystals as versatile and active catalysts for the electrooxidation of $\mathrm{C}_{1}$ fuels. Leveraging the selective coordination effect between ascorbic acid and $\mathrm{Rh}^{3+}$ ions, the doping of trace $\mathrm{Rh}$ atoms can be guided specifically at the near-surface of PtNiCoRh nanocatalysts. Electrocatalytic tests indicate that $\mathbf{P t}_{67} \mathbf{N i}_{16} \mathbf{C o}_{16} \mathbf{R h}_{1}$ nanocrystals with in situ trace Rh-doped surface exhibit substantially enhanced activity, durability, and CO tolerance for the electrooxidation of methanol, formaldehyde, and formic acid. In situ Fourier transform infrared spectroscopy provides molecular-level insight into the exceptional performance of these nanocatalysts. The surface incorporation of anticorrosive $\mathrm{Rh}$ atoms enables the transfer of $\mathrm{CO}$ intermediates from the atop $\mathrm{Pt}$ sites to the bridged $\mathrm{Rh}-\mathrm{Pt}$ surface sites, thereby facilitating the elimination of these poisoning species from the catalyst surface. This study presents an effective in situ surface doping strategy which can enable the design of more atom-economic heterocatalysts.
\end{abstract}

Keywords: Pt-based nanocatalyst, in situ surface doping, $\mathrm{Rh}-\mathrm{Pt}$ interatomic sites, electrooxidation of $\mathrm{C}_{1}$ fuels, quatermetallic nanocrystals

\section{INTRODUCTION}

A paradigm shift from the internal combustion engine to fuel cell electric vehicles has a promising outlook for mitigating the environmental deterioration and energy crisis [1]. Direct liquid fuel cells (DLFCs), in which the energy is supplied by small organic molecules (SOMs), afford a platform to convert chemical energy into electricity by efficient, green and sustainable pathways [2-5]. Spanning various SOMs, $\mathrm{C}_{1}$ fuels (methanol, formic acid and formaldehyde) are the simplest and most promising hydrogen-containing room-temperature liquids [6-11]. Notably, achieving a holistic carbon-neutral economy hinges on the source of $\mathrm{C}_{1}$ fuels. An ideal option is to transform $\mathrm{CO}_{2}$ into liquefiable $\mathrm{C}_{1}$ fuels by using renewable energy. However, the typically poor selectivity of this transformation [12-14] poses a formidable challenge in developing fuel-flexible novel electrocatalysts that are not restricted to a single $\mathrm{C}_{1}$-fuel.

$\mathrm{Pt}$ is the quintessential element for catalyzing electrooxidation of $\mathrm{C}_{1}$ fuels in acid medium [15-18]. One prevailing strategy to promote the utilization efficiency, catalytic activity and $\mathrm{CO}$ tolerance of $\mathrm{Pt}$ catalysts is to incorporate transition metals (TMs, such as $\mathrm{Ni}, \mathrm{Co}, \mathrm{Cu}$, etc.) into Pt nanostructures to form alloyed nanocatalysts [19-23]. However, these TMs inevitably leach out under harsh reaction conditions, which is unfavorable for the electrooxidation of $\mathrm{C}_{1}$ fuels and detrimental for structural stability. On the other hand, the atomic-level units on the catalyst surface can determine the reaction pathway and activation energy. Specifically, at least 2-3 adjacent $\mathrm{Pt}$ atoms are required for the effective adsorption and oxidation of a methanol molecule, while a single Pt atom can accelerate the direct oxidation of a formic acid molecule [24-30]. Therefore, more precise compositional and structural regulations are required. In a sense, doping

\footnotetext{
${ }^{1}$ College of Materials Science and Engineering, Huaqiao University, Xiamen 361021, China

${ }^{2}$ State Key Laboratory for Physical Chemistry of Solid Surfaces, Department of Chemistry and College of Chemistry and Chemical Engineering, Xiamen University, Xiamen 361005, China

${ }^{3}$ Department of Chemistry, National University of Singapore, 3 Science Drive 3, 117543, Singapore

These authors contributed equally to this work.

* Corresponding author (email: sfxie@hqu.edu.cn)
} 
anticorrosive heteroatoms at the near-surface of Pt-based catalysts, as exemplified by Au-modified $\mathrm{Pt}, \mathrm{Mo} / \mathrm{Rh}$ doped PtNi octahedral, Ga-doped $\mathrm{Pt}_{3} \mathrm{Co}$ nanowires, etc. [31-35], can not only promote the catalytic activity with improved durability but also engineer the diversity of atomically active sites. However, most reported nanomaterials of this category are bulk-phase doped. A few surface-doped materials are fabricated via two-pot synthesis, which has the disadvantages of relatively tedious processes, extra costs and elusive large-scale synthesis. In comparison, one-pot in situ surface doping possesses the potential to tackle the above limitations. However, it remains challenging due to the difficulty in regulating the reduction and nucleation processes of multiple metal precursors. Hence, it is imperative to explore an in situ surface doping strategy to carry out surface modification with robust local configurations and diverse active sites for highly efficient and atom-economic Pt-based electrocatalysts.

In this work, a ligand-assisted, in situ surface doping strategy is presented to fabricate $\mathrm{PtNiCoRh}$ assembled nanodendrites (ANDs) with trace Rh-doped surfaces. As a pioneering example to engineer the local surface configuration of a quaternary Pt-based nanostructure via in situ surface doping, the structure, elemental distribution and formation mechanism of the novel PtNiCoRh ANDs were systematically characterized. The results demonstrate that the selective coordination effect between ascorbic acid (AA) and $\mathrm{Rh}^{3+}$ cations enables the postreduction of $\mathrm{Rh}$ atoms, and thereby enriches $\mathrm{Rh}$ specifically on the near-surface of the final product. Electrocatalytic tests for methanol oxidation reaction (MOR) reveal that $\mathrm{Pt}_{67} \mathrm{Ni}_{16} \mathrm{Co}_{16} \mathrm{Rh}_{1}$ ANDs deliver the best specific activity (SA, $3.09 \mathrm{~mA} \mathrm{~cm}^{-2}$ ) and mass activity (MA, $0.86 \mathrm{~A} \mathrm{mg}^{-1}$ ), which are 9.1 and 4.1 times higher than those of state-of-the-art $\mathrm{Pt} / \mathrm{C}$ catalyst, respectively. Furthermore, $\mathrm{Pt}_{67} \mathrm{Ni}_{16} \mathrm{Co}_{16} \mathrm{Rh}_{1}$ ANDs also exhibit superior $\mathrm{CO}$ tolerance and catalytic activities in the formaldehyde oxidation reaction (FOR) and the formic acid oxidation reaction (FAOR). The reaction mechanisms of MOR and FAOR were further investigated by in situ Fourier transform infrared spectroscopy (FTIR), which provides molecular-level understanding of the electrocatalytic enhancements.

\section{EXPERIMENTAL SECTION}

\section{Chemicals and reagents}

Platinum(II) acetylacetonate ( $\left.\mathrm{Pt}(\mathrm{acac})_{2}, 97 \%\right)$ and rhodium(III) acetylacetonate $\left(\mathrm{Rh}(\mathrm{acac})_{3}, 97 \%\right)$ were pur- chased from Kunming Institute of Precious Metals; nickel(II) acetylacetonate $\left(\mathrm{Ni}(\mathrm{acac})_{2}, 97 \%\right)$, cobalt(II) acetylacetonate $\left(\mathrm{Co}(\mathrm{acac})_{2}, 97 \%\right)$, and oleylamine (OAm, $90 \%$ ) were purchased from Aladdin; $L$-ascorbic acid (AA, $\left.\mathrm{C}_{6} \mathrm{H}_{8} \mathrm{O}_{6}, \geq 99.7 \%\right)$ was purchased from Xilong Chemical Co. Ltd. (China); and commercial Pt/C (20 wt\% loading) was purchased from Johnson Matthey. All the chemicals were used as received without further purification.

\section{Synthesis method}

In a typical synthesis of $\mathrm{Pt}_{67} \mathrm{Ni}_{16} \mathrm{Co}_{16} \mathrm{Rh}_{1}$ ANDs, $\mathrm{Pt}(\mathrm{acac})_{2}$ (30 mg, $0.075 \mathrm{mmol}), \mathrm{Ni}(\mathrm{acac})_{2}(3.3 \mathrm{mg}, 0.0125 \mathrm{mmol}$ ), $\mathrm{Co}(\mathrm{acac})_{2} \quad(3.3 \mathrm{mg}, \quad 0.0125 \mathrm{mmol}), \mathrm{Rh}(\mathrm{acac})_{3}(0.4 \mathrm{mg}$, $0.001 \mathrm{mmol})$, and AA $(52.8 \mathrm{mg})$ were dissolved in OAm $(5.0 \mathrm{~mL})$ and sealed in a glass vial $(25 \mathrm{~mL})$. After the reactants were stirred and sonicated for $10 \mathrm{~min}$, the solution was heated in an oil bath at $170^{\circ} \mathrm{C}$ for $6 \mathrm{~h}$ under stirring $(360 \mathrm{rpm})$. The product was then collected by centrifugation and washed three times with $n$-hexane. For the syntheses of PtNiCoRh ANDs with other ratios of Rh, only the amount of $\mathrm{Rh}(\mathrm{acac})_{3}$ was adjusted. Specifically, $2.4 \mathrm{mg}(0.006 \mathrm{mmol}), 1.2 \mathrm{mg}(0.003 \mathrm{mmol})$, and $0 \mathrm{mg}$ $\mathrm{Rh}(\mathrm{acac})_{3}$ were added for the syntheses of $\mathrm{Pt}_{67} \mathrm{Ni}_{13} \mathrm{Co}_{15} \mathrm{Rh}_{5}$, $\mathrm{Pt}_{68} \mathrm{Ni}_{14} \mathrm{Co}_{15} \mathrm{Rh}_{3}$, and $\mathrm{Pt}_{69} \mathrm{Ni}_{13} \mathrm{Co}_{18}$ ANDs, respectively.

\section{Characterization}

Powder X-ray diffraction (PXRD) patterns were recorded on a Rigaku Smart Lab system operated at $30 \mathrm{~mA}$ and $40 \mathrm{kV}$ using $\mathrm{Cu} \mathrm{Ka}$ radiation $(\lambda=1.5418 \AA)$. Transmission electron microscopy (TEM), high-resolution TEM (HRTEM), high-angle annular dark-field scanning TEM (HAADF-STEM), and energy-dispersive X-ray spectroscopy (EDS) analyses were performed on an FEI Talos F200s system operating at $200 \mathrm{kV}$. X-ray photoelectron spectroscopy (XPS) was performed on a Thermo Fisher Scientific ESCALAB 250 spectrometer using monochromatic $\mathrm{Al} \mathrm{Ka} \mathrm{X}$-ray $(150 \mathrm{~W}, 20 \mathrm{eV}$ pass energy). Inductively coupled plasma mass spectrometry (ICP-MS) was conducted on an Agilent 7800 system. X-ray absorption spectra were collected on a beamline BL01C1 system in National Synchrotron Radiation Research Center (NSRRC, Hsinchu, Taiwan), and technical support was provided by Ceshigo Research Service (www. ceshigo.com). The radiation was monochromatized by a $\mathrm{Si}(111)$ double-crystal monochromator. Data were processed and analyzed by Athena software.

\section{Electrochemical measurements}

Electrochemical measurements were carried out on a standard three-electrode system at room temperature 
with a CHI 660E electrochemical workstation (Shanghai Chenhua Co., Ltd., China). A Pt mesh $(1.0 \mathrm{~cm} \times 1.0 \mathrm{~cm})$ and a saturated calomel electrode (SCE) were employed as the counter and reference electrodes, respectively. The working electrode was a glassy carbon electrode (GCE, area: $0.196 \mathrm{~cm}^{2}$ ) modified with electrocatalysts. The modification was performed by casting $5.0 \mu \mathrm{L}$ ink dispersion $\left(1.0 \mathrm{mg}_{\mathrm{Pt}} \mathrm{mL}^{-1}\right)$ on the GCE, which was then dried under IR lamp irradiation. Electrochemically active surface areas (ESCAs) were determined by cyclic voltammetry $(\mathrm{CV})$ in $\mathrm{N}_{2}$-saturated $0.5 \mathrm{~mol} \mathrm{~L}^{-1} \mathrm{H}_{2} \mathrm{SO}_{4}$ electrolyte with a scan rate of $50 \mathrm{mV} \mathrm{s}^{-1}$. For the $\mathrm{CO}$ stripping tests, GCE was first immersed in CO-saturated $0.5 \mathrm{~mol} \mathrm{~L}^{-1} \mathrm{H}_{2} \mathrm{SO}_{4}$ electrolyte for $15 \mathrm{~min}$, and then transferred into freshly $\mathrm{N}_{2}$-deaerated $0.5 \mathrm{~mol} \mathrm{~L}^{-1} \mathrm{H}_{2} \mathrm{SO}_{4}$ to conduct the $\mathrm{CO}$ stripping voltammetry between -0.2 and $1.0 \mathrm{~V}$ with a scan rate of $20 \mathrm{mV} \mathrm{s}^{-1}$. For the electrocatalytic measurements of $\mathrm{C}_{1}$ fuels, the tests were conducted in $0.5 \mathrm{~mol} \mathrm{~L}^{-1} \mathrm{H}_{2} \mathrm{SO}_{4}+0.5 \mathrm{~mol} \mathrm{~L}^{-1}$ methanol, $0.5 \mathrm{~mol} \mathrm{~L}^{-1} \mathrm{H}_{2} \mathrm{SO}_{4}+0.5 \mathrm{~mol} \mathrm{~L}^{-1}$ formaldehyde, and $0.5 \mathrm{~mol} \mathrm{~L}^{-1} \mathrm{H}_{2} \mathrm{SO}_{4}+0.5 \mathrm{~mol} \mathrm{~L}^{-1}$ formic acid with a scan rate of $50 \mathrm{mV} \mathrm{s}^{-1}$, respectively. All the electrode potentials in this paper are quoted versus the SCE.

\section{In situ FTIR measurements}

Electrochemical in situ FTIR spectroscopic studies were conducted on a Nexus 870 FTIR spectrometer (Nicolet) equipped with a liquid-nitrogen-cooled MCT-A detector and an EverGlo IR source. The spectral resolution was ca. $8 \mathrm{~cm}^{-1}$. During the measurements, infrared radiation sequentially passed through a $\mathrm{CaF}_{2}$ window and a thin-layer solution (about $10 \mu \mathrm{m}$ ), and then it was reflected by the electrode surface. The resulting spectra were reported using the relative change of reflectivity, which is defined by the following equation:

$\frac{\Delta R}{R}=\frac{R\left(E_{\mathrm{S}}\right)-R\left(E_{\mathrm{R}}\right)}{R\left(E_{\mathrm{R}}\right)}$,

where $R\left(E_{\mathrm{S}}\right)$ and $R\left(E_{\mathrm{R}}\right)$ are the single-beam spectra collected at the sample potential $E_{\mathrm{S}}$ and reference potential $E_{\mathrm{R}}\left(E_{\mathrm{R}}=-0.20 \mathrm{~V}\right.$ vs. SCE $)$, respectively.

\section{RESULTS AND DISCUSSION}

\section{Characterization of the in situ surface-doped PtNiCoRh ANDs}

The in situ surface doping of quatermetallic PtNiCoRh ANDs was implemented by manipulating the coordination environment to achieve the stepwise reduction of various precursors, including $\mathrm{Pt}(\mathrm{acac})_{2}, \mathrm{Ni}(\mathrm{acac})_{2}$,
$\mathrm{Co}(\mathrm{acac})_{2}$, and $\mathrm{Rh}(\mathrm{acac})_{3}$, in a one-pot colloidal method (see the EXPERIMENTAL SECTION for details). Fig. 1a presents a schematic illustration of the ligand-assisted in situ surface doping of Rh. By the selective coordination of $\mathrm{AA}$ with $\mathrm{Rh}^{3+}$ in the oil phase solution [36], the reduction can be delayed and the near-surface doping of Rh can be realized. Fig. $1 b$ and $c$ are the large-area HAADF-STEM and TEM images of the obtained products, which show uniformly porous nanostructures composed of multibranched subunits with average diameters of 4-5 $\mathrm{nm}$. The magnified TEM image verifies the high porosity of the products (Fig. 1d), which have abundant inner channels to improve the mass transportation of reactants and products during the catalysis process [37-39]. HRTEM image shows that the lattice fringe is $0.221 \mathrm{~nm}$, which is slightly smaller than the face-centered cubic (fcc) $\operatorname{Pt}(111)$ facets $(0.227 \mathrm{~nm})$, indicating the formation of PtNiCoRh alloys (Fig. S1). In addition, the jagged surface of the nanobranch indicates exposed atomic steps. The overall $\mathrm{Pt} / \mathrm{Ni} / \mathrm{Co} / \mathrm{Rh}$ atomic ratio is determined to be $67 / 16 / 16 / 1$ by ICP-MS (denoted as $\mathrm{Pt}_{67} \mathrm{Ni}_{16} \mathrm{Co}_{16} \mathrm{Rh}_{1}$ ANDs). STEMEDS elemental mappings and cross-sectional line profiles reveal that $\mathrm{Pt}, \mathrm{Ni}, \mathrm{Co}$, and $\mathrm{Rh}$ elements are uniformly distributed over the entire sample (Fig. 1e and f). PXRD pattern shows a single set of diffraction peaks indexed to the fcc crystalline structure (Fig. 1g), indicating the formation of alloys. Compared to the pure Pt crystal (JCPDS No. 65-2868), the shifts of diffraction peaks reflect lattice contraction, attributed to the replacement of $\mathrm{Pt}$ atoms by the smaller $\mathrm{Ni}, \mathrm{Co}$, and $\mathrm{Rh}$ atoms.

One of the main merits of the proposed in situ surface doping strategy is that a series of PtNiCoRh ANDs with various trace amounts of Rh can be successfully fabricated by regulating the amount of added $\mathrm{Rh}(\mathrm{acac})_{3}$. In general, all the products with different levels of Rh doping exhibit similar dendritic structures and abundant interconnected channels (Figs S2-S4). Moreover, PXRD patterns confirm that all these samples are pure fcc phase alloys (Fig. S5). As determined by ICP-MS, these samples were denoted as $\mathrm{Pt}_{69} \mathrm{Ni}_{13} \mathrm{Co}_{18}, \quad \mathrm{Pt}_{68} \mathrm{Ni}_{14} \mathrm{Co}_{15} \mathrm{Rh}_{3}$, and $\mathrm{Pt}_{67} \mathrm{Ni}_{13} \mathrm{Co}_{15} \mathrm{Rh}_{5}$ ANDs, respectively. To gain a better understanding of the near-surface composition of the as-prepared nanocrystals, surface-sensitive XPS analysis was conducted (Fig. 2a-c). The results show that the surface Rh concentrations of the Rh-doped PtNiCoRh samples are consistently higher than those of the integral ones, as determined by the ICP-MS (Fig. 2d). The diverse $\mathrm{Rh}$ population verifies the successful preparation of the near-surface Rh-doped PtNiCoRh alloys and the feasibility of the in situ surface doping technique. 

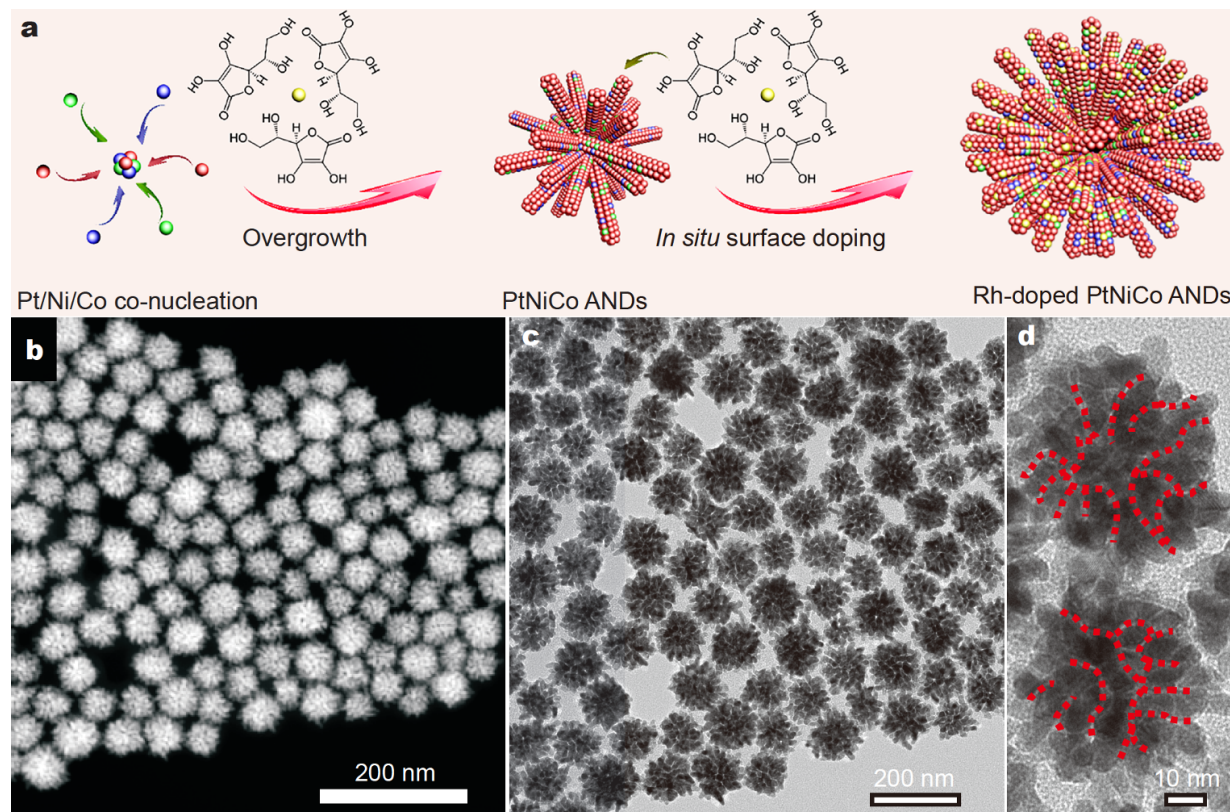

PtNiCo ANDs

Rh-doped PtNiCo ANDs
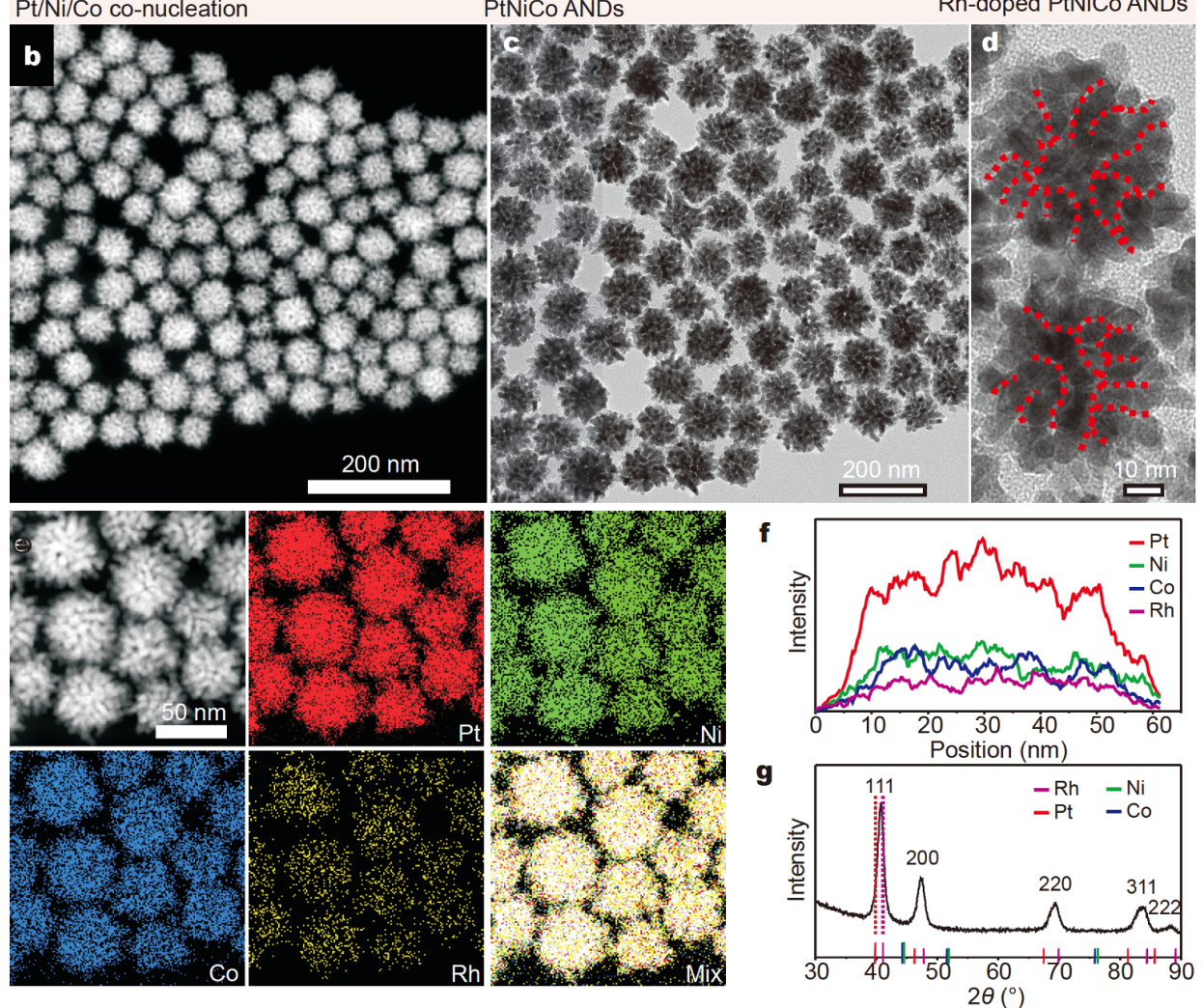

Figure 1 Synthesis scheme and characterizations of the $\mathrm{Pt}_{67} \mathrm{Ni}_{16} \mathrm{Co}_{16} \mathrm{Rh}_{1}$ ANDs. (a) Schematic illustration of the in situ surface doping of PtNiCoRh ANDs (red: Pt, green: Ni, blue: Co, yellow: Rh); (b) HAADF-STEM image; (c) TEM image; (d) magnified TEM image; (e) HAADF-STEM and EDS mapping images; (f) profiled EDS line scans and (g) PXRD patterns.

X-ray absorption near-edge spectroscopy (XANES) and extended X-ray fine structure (EXAFS) analyses were performed to determine the electronic and local structural nature of $\mathrm{Rh}$ species at atomic level. Fig. 3a shows the normalized $\mathrm{Rh}$ K-edge XANES profiles of $\mathrm{Pt}_{67} \mathrm{Ni}_{16^{-}}$ $\mathrm{Co}_{16} \mathrm{Rh}_{1}$ ANDs, with $\mathrm{Rh}$ foil and $\mathrm{Rh}_{2} \mathrm{O}_{3}$ for references. According to the lower energy for absorption edge and the weaker intensity for white line in the Rh K-edge XANES profiles, it can be deduced that $\mathrm{Rh}$ species in $\mathrm{Pt}_{67} \mathrm{Ni}_{16} \mathrm{Co}_{16} \mathrm{Rh}_{1}$ ANDs are mainly in the metallic state, which resembles that of $\mathrm{Rh}$ foil with a zero valence state. As shown in EXAFS in R space (Fig. 3b), no Rh-O peak can be observed for $\mathrm{Pt}_{67} \mathrm{Ni}_{16} \mathrm{Co}_{16} \mathrm{Rh}_{1}$ ANDs, in good agreement with the Rh K-edge XANES result. Furthermore, $\mathrm{Pt}_{67} \mathrm{Ni}_{16} \mathrm{Co}_{16} \mathrm{Rh}_{1}$ ANDs exhibit a visibly broadened peak, which can be attributed to the superimposed $\mathrm{Rh}-\mathrm{Rh}$ and $\mathrm{Rh}-\mathrm{Pt}$ peaks according to the fitting result (Table S1). This result verifies the diversity of atomic active sites on the surface of $\mathrm{Pt}_{67} \mathrm{Ni}_{16} \mathrm{Co}_{16} \mathrm{Rh}_{1}$ ANDs via the in situ surface doping strategy.

\section{The in situ surface doping mechanism}

The formation mechanism of the quaternary PtNiCoRh ANDs with Rh-doped near surfaces, as exemplified by $\mathrm{Pt}_{67} \mathrm{Ni}_{16} \mathrm{Co}_{16} \mathrm{Rh}_{1}$ ANDs, was investigated by monitoring the time-evolving STEM and ICP-MS results. STEM images indicate that $\mathrm{Pt}_{67} \mathrm{Ni}_{16} \mathrm{Co}_{16} \mathrm{Rh}_{1}$ ANDs are generated following a rapid-growth mode, in which small clusters are initially formed as seeds and then grow into dendritic nanostructures (Fig. S6). Although the equilibrium po- 

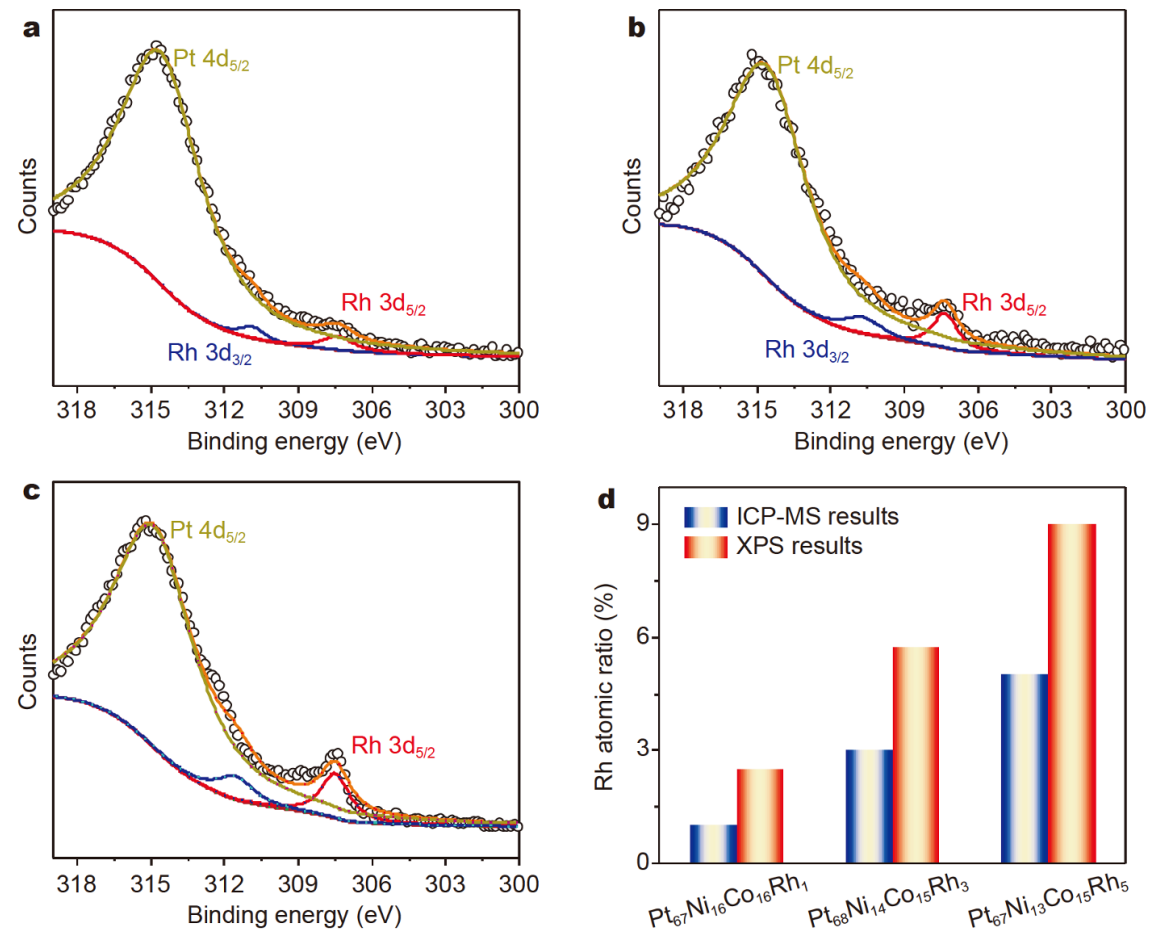

Figure 2 Near-surface and bulk phase Rh concentration analyses. XPS data of (a) $\mathrm{Pt}_{67} \mathrm{Ni}_{16} \mathrm{Co}_{16} \mathrm{Rh}_{1}$, (b) $\mathrm{Pt}_{68} \mathrm{Ni}_{14} \mathrm{Co}_{15} \mathrm{Rh}_{3}$, and (c) $\mathrm{Pt}_{67} \mathrm{Ni}_{13} \mathrm{Co}_{15} \mathrm{Rh}_{5}$ ANDs. (d) Histograms of XPS and ICP-MS results of the above samples.
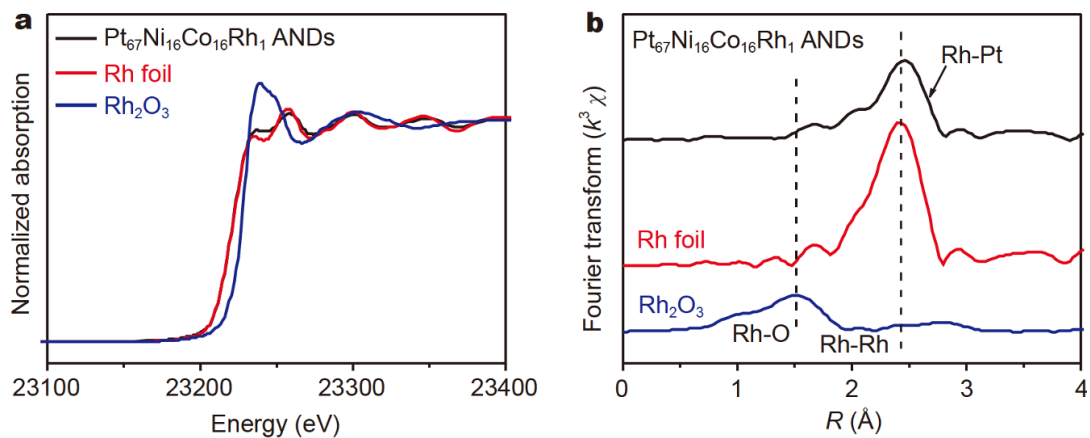

Figure 3 Local electronic and atomic structures of $\mathrm{Pt}_{67} \mathrm{Ni}_{16} \mathrm{Co}_{16} \mathrm{Rh}_{1}$ ANDs. (a) Rh K-edge XANES spectra and (b) Fourier transformed (FT) $k^{3}$ weighted $\mathrm{w}(k)$-function of EXAFS spectra for $\mathrm{Pt}_{67} \mathrm{Ni}_{16} \mathrm{Co}_{16} \mathrm{Rh}_{1}$ ANDs (black) with the corresponding $\mathrm{Rh}$ foil (red) and $\mathrm{Rh}_{2} \mathrm{O}_{3}(\mathrm{blue})$ references.

tential of $\mathrm{Rh}^{3+}$ reduction $(0.758 \mathrm{~V} v$ s. standard hydrogen electrode (SHE)) is significantly more positive than that of $\mathrm{Co}^{2+}\left(-0.277 \mathrm{~V}\right.$ vs. SHE) and $\mathrm{Ni}^{2+}(-0.257 \mathrm{~V}$ vs. SHE $)$ [40], Rh element cannot be detected until 120 min reaction based on the ICP-MS measurements (Fig. S7). On the contrary, large amounts of $\mathrm{Co}$ and $\mathrm{Ni}$ are detected at the early stage of the reaction. These results indicate that a step-by-step reduction mechanism is followed during the fabrication of $\mathrm{Pt}_{67} \mathrm{Ni}_{16} \mathrm{Co}_{16} \mathrm{Rh}_{1}$ ANDs, which favors the enrichment of $\mathrm{Rh}$ on the near-surface regions of nanodendrite (Fig. 1a).
To further clarify the in situ surface doping process, a set of control experiments were also conducted. For example, Rh-free PtNiCo ANDs were obtained under excess $\mathrm{AA}-\mathrm{Rh}^{3+}$ coordination conditions when the addition amount of AA increased from 52.8 to $210 \mathrm{mg}$ but the other parameters were kept unchanged. On the other hand, non-assembled nanoparticles with similar $\mathrm{Rh}$ content to $\mathrm{Pt}_{67} \mathrm{Ni}_{16} \mathrm{Co}_{16} \mathrm{Rh}_{1}$ ANDs were obtained without the addition of AA (Fig. S8). These results indicate that the selective coordination effect of AA with $\mathrm{Rh}^{3+}$ induces the delayed reduction of $\mathrm{Rh}^{3+}$ and thus realizes the surface 
doping of Rh. To verify this deduction, the time-dependent evolution of the samples synthesized without $\mathrm{AA}$ was further monitored (Fig. S9). Unlike $\mathrm{Pt}_{67} \mathrm{Ni}_{16} \mathrm{Co}_{16} \mathrm{Rh}_{1}$ ANDs, the inclusion of $\mathrm{Rh}$ in the non-assembled nanoparticles can be rapidly discerned within $10 \mathrm{~min}$, providing compelling evidence of the selective AA coordination toward $\mathrm{Rh}^{3+}$ in the standard synthesis. Here, the proposed in situ surface doping strategy at the atomic level not only improves the atomic utilization but also enriches the diversity of surface atomic sites.

\section{Electrooxidation of $\mathrm{C}_{1}$ fuels}

To investigate the electrocatalytic performance of the in situ surface-doped PtNiCoRh ANDs, MOR was selected as the target reaction. ECSAs were initially evaluated by normalizing the stripping charges of the underpotential deposited hydrogen $\left(\mathrm{H}_{\text {upd }}\right)$ with a value of $210 \mu \mathrm{C} \mathrm{cm}^{-2}$ as measured by $\mathrm{CV}$ in $\mathrm{N}_{2}$-saturated $0.5 \mathrm{~mol} \mathrm{~L}^{-1} \mathrm{H}_{2} \mathrm{SO}_{4}$ solution (Fig. 4a). Specifically, $\mathrm{Pt}_{69} \mathrm{Ni}_{13} \mathrm{Co}_{18}, \mathrm{Pt}_{67} \mathrm{Ni}_{16} \mathrm{Co}_{16^{-}}$ $\mathrm{Rh}_{1}, \mathrm{Pt}_{68} \mathrm{Ni}_{14} \mathrm{Co}_{15} \mathrm{Rh}_{3}, \mathrm{Pt}_{67} \mathrm{Ni}_{13} \mathrm{Co}_{15} \mathrm{Rh}_{5}$ ANDs, and commercial Pt/C have ECSA values of 24.85, 27.66, 23.26, 21.74 , and $61.79 \mathrm{~m}^{2} \mathrm{~g}_{\mathrm{Pt}}^{-1}$, respectively. Subsequently, MOR CV was conducted in $0.5 \mathrm{~mol} \mathrm{~L}^{-1} \mathrm{H}_{2} \mathrm{SO}_{4}$ solution containing $0.5 \mathrm{~mol} \mathrm{~L}^{-1}$ methanol (Fig. $4 \mathrm{~b}$ ). $\mathrm{Pt}_{67} \mathrm{Ni}_{16} \mathrm{Co}_{16}$ $\mathrm{Rh}_{1}$ ANDs display the highest MA $\left(0.86 \mathrm{~A} \mathrm{mg}^{-1}{ }_{\mathrm{Pt}}\right)$ and SA $\left(3.09 \mathrm{~mA} \mathrm{~cm}^{-2}\right.$ ), which are $\sim 4.1$ and $\sim 9.1$ times, respec-
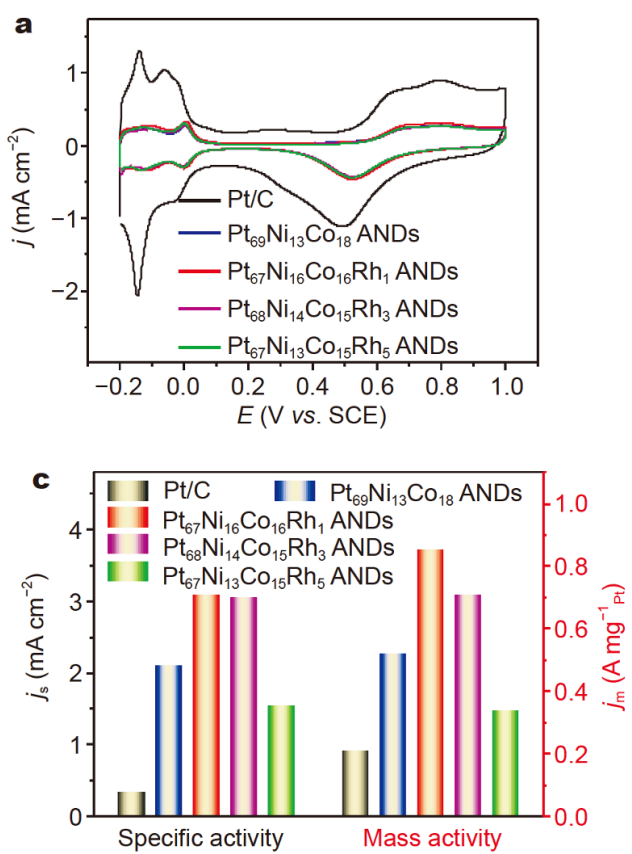

tively, higher than those of Pt/C (Fig. 4c). In comparison, $\mathrm{Pt}_{69} \mathrm{Ni}_{13} \mathrm{Co}_{18}$ ANDs only have MA of $0.52 \mathrm{~A} \mathrm{mg}^{-1} \mathrm{Pt}$ and $\mathrm{SA}$ of $2.10 \mathrm{~mA} \mathrm{~cm}^{-2}$. With further increase in the Rhdoping amount, the resulting $\mathrm{Pt}_{68} \mathrm{Ni}_{14} \mathrm{Co}_{15} \mathrm{Rh}_{3}$ and $\mathrm{Pt}_{67} \mathrm{Ni}_{13} \mathrm{Co}_{15} \mathrm{Rh}_{5}$ ANDs also exhibit smaller MA (0.70 and $0.34 \mathrm{~A} \mathrm{mg}^{-1}$ t) and SA (3.04 and $1.55 \mathrm{~mA} \mathrm{~cm}^{-2}$ ) values. Therefore, it is vital to precisely engineer the surface doping degree of $\mathrm{Rh}$ to prevent the excessive displacement of the active Pt surface sites. In addition, $\mathrm{Pt}_{67} \mathrm{Ni}_{16}$ $\mathrm{Co}_{16} \mathrm{Rh}_{1}$ ANDs exhibit much better MOR activity than $\mathrm{Pt}_{99} \mathrm{Rh}_{1}$ ANDs (Fig. S10), indicating that the alloying effect of introduced $\mathrm{Ni}$ and $\mathrm{Co}$ is conducive to MOR enhancement [19,20]. Notably, the MA achieved by $\mathrm{Pt}_{67} \mathrm{Ni}_{16} \mathrm{Co}_{16} \mathrm{Rh}_{1}$ ANDs is superior to most of the reported Pt-based MOR catalysts (Table S2). Finally, chronoamperometry (CA, $E=0.62 \mathrm{~V} v s$. SCE) was performed to examine the durability of the catalysts (Fig. $4 \mathrm{~d}$ ). Within the measurement time, PtNiCoRh ANDs with various surface-doped $\mathrm{Rh}$ contents retained reasonable activities and $\mathrm{Pt}_{67} \mathrm{Ni}_{16} \mathrm{Co}_{16} \mathrm{Rh}_{1}$ ANDs displayed the highest steady current density. One of the dendritic nanostructures, i.e., $\mathrm{Pt}_{67} \mathrm{Ni}_{16} \mathrm{Co}_{16} \mathrm{Rh}_{1}$ ANDs, was selected to compare the morphological and compositional changes before and after the CA test. In the HAADF-STEM and element mapping images, no discernible changes can be observed (Fig. S11). Furthermore, ICP-MS result shows that the
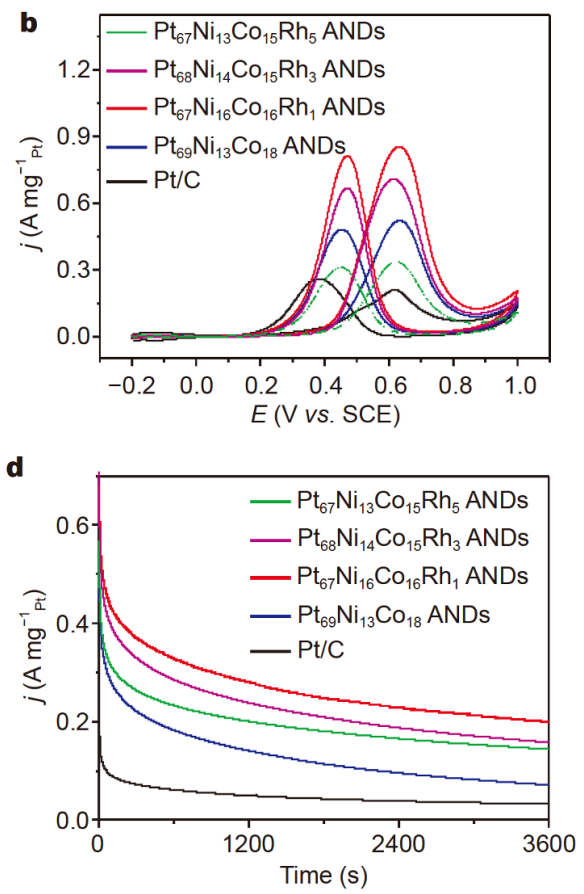

Figure 4 Electrocatalytic tests of $\mathrm{Pt}_{69} \mathrm{Ni}_{13} \mathrm{Co}_{18}, \mathrm{Pt}_{67} \mathrm{Ni}_{16} \mathrm{Co}_{16} \mathrm{Rh}_{1}, \mathrm{Pt}_{68} \mathrm{Ni}_{14} \mathrm{Co}_{15} \mathrm{Rh}_{3}, \mathrm{Pt}_{67} \mathrm{Ni}_{13} \mathrm{Co}_{15} \mathrm{Rh}_{5}$ ANDs and commercial Pt/C. (a) CV curves; (b) MOR CVs of mass activity; (c) histograms of specific activity and mass activity; (d) chronoamperometric measurements. 
atomic ratio of $\mathrm{Pt} / \mathrm{Ni} / \mathrm{Co} / \mathrm{Rh}$ changes from $67: 16: 16: 1$ to 77:8:14:1, exhibiting partial decrease in $\mathrm{Ni}$ and Co contents but imperceptible decrease in $\mathrm{Rh}$ content. Therefore, it can be concluded that the in situ surface doping of $\mathrm{Rh}$ into Pt-based nanostructures endows them with excellent electrocatalytic durability.

To further exploit the electrooxidation reactions of other $\mathrm{C}_{1}$ fuels, a series of $\mathrm{CO}$-stripping experiments were first performed to evaluate the anti-poisoning ability of $\mathrm{PtNiCoRh}$ ANDs. A clear negative-shift in peak-potential of the CO-stripping wave for $\mathrm{Pt}_{67} \mathrm{Ni}_{16} \mathrm{Co}_{16} \mathrm{Rh}_{1}$ ANDs is observed compared with those for $\mathrm{Pt}_{69} \mathrm{Ni}_{13} \mathrm{Co}_{18}$ ANDs and $\mathrm{Pt} / \mathrm{C}$ (Fig. 5a), demonstrating enhanced $\mathrm{CO}$ tolerance. Then, the electrocatalytic performances of FOR and FAOR were studied through linear potential sweeps. For the electrooxidation of both formaldehyde (Fig. 5b) and formic acid (Fig. 5c), $\mathrm{Pt}_{67} \mathrm{Ni}_{16} \mathrm{Co}_{16} \mathrm{Rh}_{1}$ ANDs deliver the highest MA values. Interestingly, on the anodic sweep of the FAOR voltammogram, there are two peaks occurring at $\sim 0.3$ and $0.7 \mathrm{~V}(v s$. SCE) during the positive-going scans, respectively. According to the previous study [41], these two peaks can be ascribed to the oxidation of formic acid via dehydrogenation (peak I) and dehydration (peak II), respectively. Moreover, $\mathrm{Pt}_{67} \mathrm{Ni}_{16} \mathrm{Co}_{16} \mathrm{Rh}_{1}$ ANDs possess higher currents for both the anodic peaks, implying that they provide faster reaction kinetics and effectively accelerate both the dehydrogenation and dehydration reaction pathways for FAOR. In brief, the in situ surface doping technique enables the fabrication of fuel-flexible and robust quaternary Pt-based nanocatalysts for the electrooxidation of $\mathrm{C}_{1}$ fuels.

\section{In situ FTIR of MOR and FAOR}

To gain molecular-level insight into the MOR and FAOR reaction process, in situ electrochemical FTIR measurements were conducted on $\mathrm{Rh}$-free $\mathrm{Pt}_{69} \mathrm{Ni}_{13} \mathrm{Co}_{18}$ and trace Rh-doped $\mathrm{Pt}_{67} \mathrm{Ni}_{16} \mathrm{Co}_{16} \mathrm{Rh}_{1}$ ANDs under the same electrocatalytic conditions. Fig. $6 \mathrm{a}$ and $\mathrm{b}$ present the potential-dependent FTIR spectra of the MOR process recorded from -0.15 to $0.3 \mathrm{~V}$ with a sampling interval of $0.05 \mathrm{~V}$. The negative IR band at ca. $2342 \mathrm{~cm}^{-1}$ corresponds to the asymmetric stretching vibration of $\mathrm{CO}_{2}$ diffused in the solution [42-44]. The bipolar bands at ca. $2043 \mathrm{~cm}^{-1}$ and the negative band at ca. $1823 \mathrm{~cm}^{-1}$ can be attributed to the $\mathrm{C}-\mathrm{O}$ stretching vibrations of adsorbed $\mathrm{CO}$ on the atop $\left(\mathrm{CO}_{\mathrm{L}}\right)$ and bridge $\left(\mathrm{CO}_{\mathrm{B}}\right)$ sites, respectively [44-46]. As shown in Fig. 6c, the potential-dependence of the band areas of $\mathrm{CO}_{2}$ is consistent with the anodic waves in the voltammetry test (Fig. $4 \mathrm{~b}$ ), indicating that $\mathrm{CO}_{2}$ molecules are formed by the complete oxidation of methanol. Moreover, $\mathrm{CO}_{\mathrm{L}}$ and $\mathrm{CO}_{\mathrm{B}}$ adsorbates are derived from the dissociation of methanol on the surfaces of
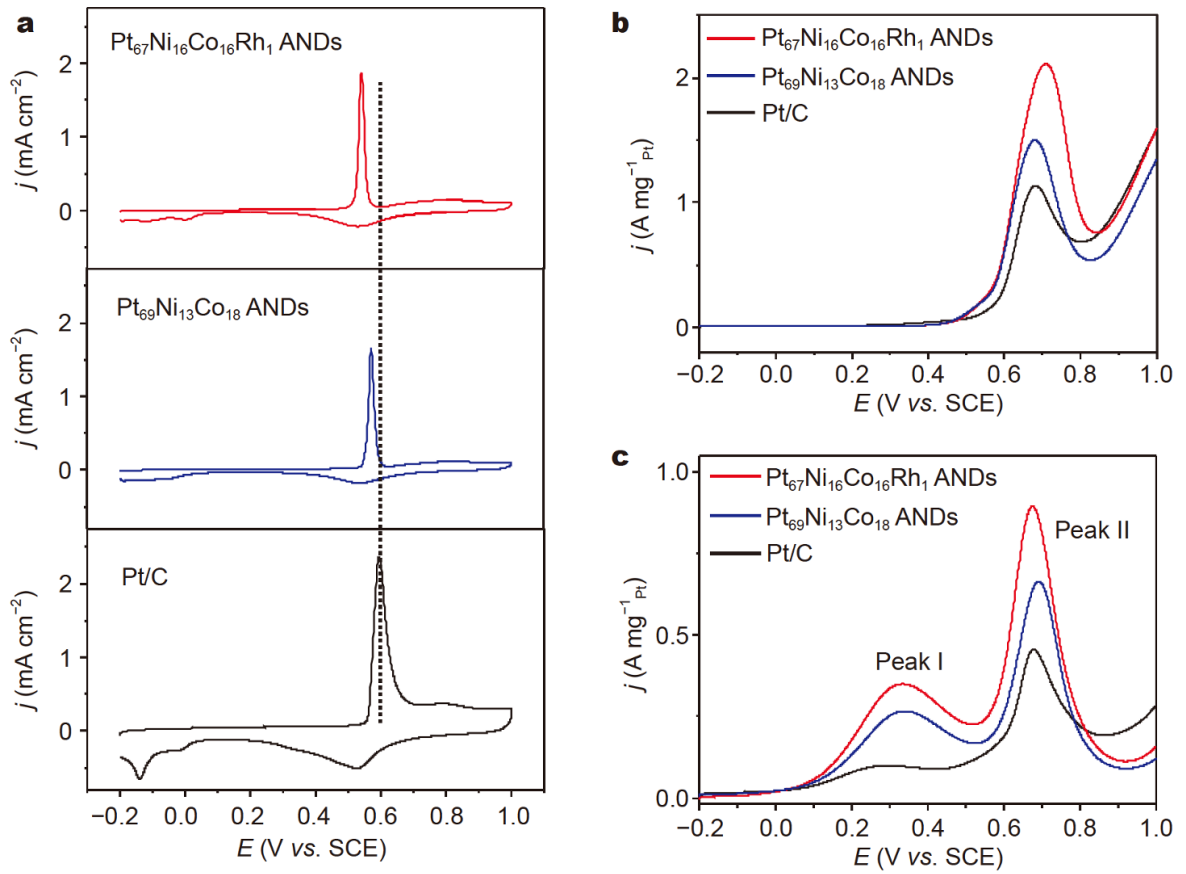

Figure 5 The electrooxidation catalysis of other $\mathrm{C}_{1}$ fuels with $\mathrm{Pt}_{69} \mathrm{Ni}_{13} \mathrm{Co}_{18}, \mathrm{Pt}_{67} \mathrm{Ni}_{16} \mathrm{Co}_{16} \mathrm{Rh}_{1}$ ANDs, and commercial Pt/C. (a) CO stripping, (b) FOR, and (c) FAOR voltammograms. 
a

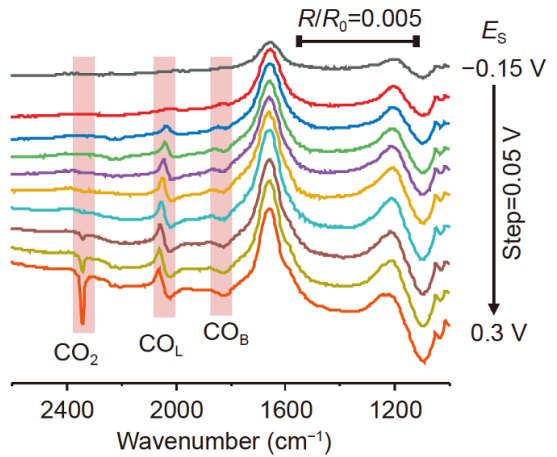

b

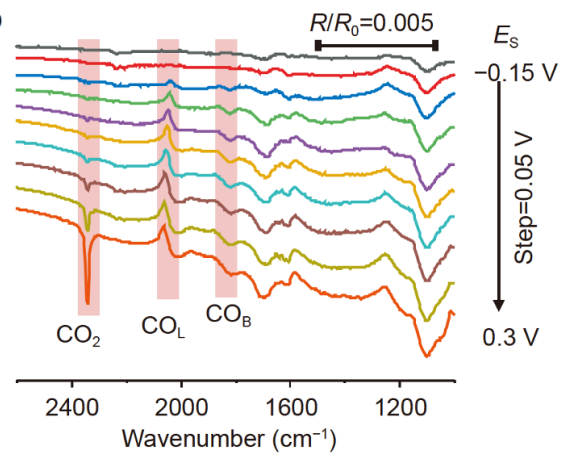

c

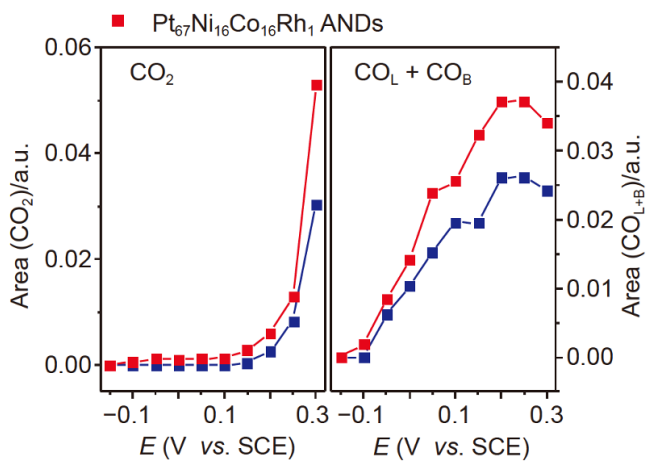

d

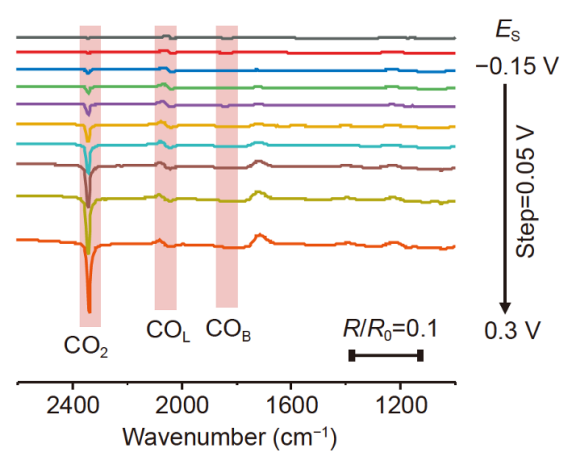

e

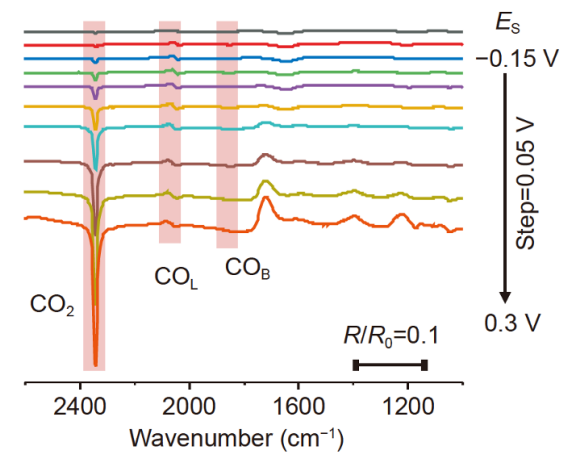

f

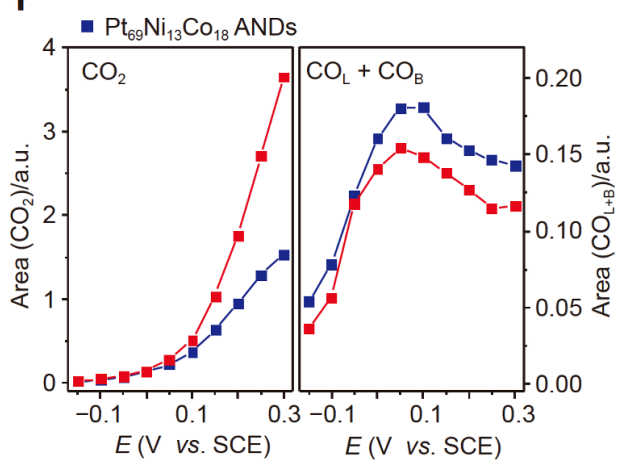

Figure 6 In situ FTIR analysis of MOR on (a) $\mathrm{Pt}_{69} \mathrm{Ni}_{13} \mathrm{Co}_{18}$ and (b) $\mathrm{Pt}_{67} \mathrm{Ni}_{16} \mathrm{Co}_{16} \mathrm{Rh}_{1} \mathrm{ANDs}$ (c) integrated intensity of CO $\mathrm{CO}_{2}$ and $\mathrm{CO}_{\mathrm{L}}+\mathrm{CO}_{\mathrm{B}}$. In situ FTIR analysis of FAOR on (d) $\mathrm{Pt}_{69} \mathrm{Ni}_{13} \mathrm{Co}_{18}$ and (e) $\mathrm{Pt}_{67} \mathrm{Ni}_{16} \mathrm{Co}_{16} \mathrm{Rh}_{1}$ ANDs; (f) integrated intensity of $\mathrm{CO}_{2}$ and $\mathrm{CO}_{\mathrm{L}}+\mathrm{CO}_{\mathrm{B}}$. (reference potential $E_{\mathrm{R}}=-0.20 \mathrm{~V}$, vs. SCE).

$\mathrm{Pt}_{69} \mathrm{Ni}_{13} \mathrm{Co}_{18}$ and $\mathrm{Pt}_{67} \mathrm{Ni}_{16} \mathrm{Co}_{16} \mathrm{Rh}_{1}$ ANDs, indicating the indirect oxidation pathway of the MOR where $\mathrm{CO}$ intermediates are included. The converse trend of the potential-intensity correlations of the $\mathrm{CO}$ adsorbates $\left(\mathrm{CO}_{\mathrm{L}}+\right.$ $\mathrm{CO}_{\mathrm{B}}$ ) and $\mathrm{CO}_{2}$ beyond $0.2 \mathrm{~V}$ also corroborates the above inference. In comparison, $\mathrm{Pt}_{67} \mathrm{Ni}_{16} \mathrm{Co}_{16} \mathrm{Rh}_{1}$ ANDs exhibit higher MOR activities as verified by both IR spectral and voltammetric investigations. Intriguingly, $\mathrm{CO}_{B}$ accounts for ca. $40 \%$ of all $\mathrm{CO}$ adsorbates on $\mathrm{Pt}_{67} \mathrm{Ni}_{16} \mathrm{Co}_{16} \mathrm{Rh}_{1}$ ANDs (Fig. S12), affirming the existence of interatomic $\mathrm{Rh}-\mathrm{Pt}$ surface sites [47-49], which serve as the MOR active centers as suggested by our previous work and others $[44,50]$.

The potential-dependent FTIR spectra of the FAOR conducted with $\mathrm{Pt}_{69} \mathrm{Ni}_{13} \mathrm{Co}_{18}$ and $\mathrm{Pt}_{67} \mathrm{Ni}_{16} \mathrm{Co}_{16} \mathrm{Rh}_{1}$ ANDs are shown in Fig. 6d, e, respectively, where vibrational bands of the dissolved $\mathrm{CO}_{2}$ and the adsorbed $\mathrm{CO}_{\mathrm{L}}$ and $\mathrm{CO}_{\mathrm{B}}$ are the prominent features. Again, the formation of $\mathrm{CO}_{2}$ follows the anodic wave of the voltammetry curves (Fig. $5 \mathrm{c}$ ), and $\mathrm{CO}_{\mathrm{L}}$ and $\mathrm{CO}_{\mathrm{B}}$ are generated from the dissociation of formic acid (Fig. 6f). The difference is that more $\mathrm{CO}_{2}$ is detected on $\mathrm{Pt}_{67} \mathrm{Ni}_{16} \mathrm{Co}_{16} \mathrm{Rh}_{1}$ ANDs, and the corresponding $\mathrm{CO}$ adsorbates are less compared with those on $\mathrm{Pt}_{69} \mathrm{Ni}_{13} \mathrm{Co}_{18}$ ANDs. This indicates improved 
reaction kinetics as well as increased portion of the dehydrogenation pathway when $\mathrm{Pt}_{67} \mathrm{Ni}_{16} \mathrm{Co}_{16} \mathrm{Rh}_{1}$ ANDs, featuring copious interatomic $\mathrm{Rh}-\mathrm{Pt}$ surface sites, are used.

\section{CONCLUSIONS}

This work introduces an in situ surface doping strategy to fabricate PtNiCoRh ANDs with controllable near-surface local-configuration and abundant interatomic $\mathrm{Rh}-\mathrm{Pt}$ surface sites. The success of the in situ near-surface doping hinges on the selective coordination between $\mathrm{AA}$ and $\mathrm{Rh}^{3+}$ cations, which enables the stepwise reduction of multiple metallic precursors and the surface confinement of $\mathrm{Rh}$ atoms. Extensive electrocatalytic measurements indicate that $\mathrm{Pt}_{67} \mathrm{Ni}_{16} \mathrm{Co}_{16} \mathrm{Rh}_{1}$ ANDs deliver the highest mass activity for MOR, FOR, and FAOR with enhanced CO tolerance and durability. In situ FTIR studies show that the interatomic Rh-Pt surface sites, constructed by the incorporation of anticorrosive $\mathrm{Rh}$ atoms, enable the transfer of $\mathrm{CO}_{\mathrm{L}}$ to $\mathrm{CO}_{\mathrm{B}}$ intermediates, which are more reactive and readily eliminated from the catalyst surface. This work not only presents a versatile Pt-based catalyst for the electrooxidation of $\mathrm{C}_{1}$ fuels but also offers an effective in situ surface doping strategy at the atomic level to fabricate atom-economic electrocatalysts.

Received 29 June 2020; accepted 9 September 2020;

published online 20 November 2020

1 Altenburg T. From combustion engines to electric vehicles: a study of technological path creation and disruption in Germany. Discussion Paper: 2014

2 Parsons R, VanderNoot T. The oxidation of small organic molecules. J Electroanal Chem Interf Electrochem, 1988, 257: 9-45

3 U.S. Department of Energy. Fuel cell technical team roadmap. 2013. http://energy.gov/sites/prod/files/2014/02/f8/fctt_roadmap_june2013.pdf

4 Zhao F, Yuan Q, Luo B, et al. Surface composition-tunable octahedral $\mathrm{PtCu}$ nanoalloys advance the electrocatalytic performance on methanol and ethanol oxidation. Sci China Mater, 2019, 62: 1877-1887

5 Ong BC, Kamarudin SK, Basri S. Direct liquid fuel cells: A review. Int J Hydrogen Energy, 2017, 42: 10142-10157

6 Huang L, Zhang W, Li P, et al. Exposing Cu-rich $\{110\}$ active facets in $\mathrm{PtCu}$ nanostars for boosting electrochemical performance toward multiple liquid fuels electrooxidation. Nano Res, 2019, 12: 1147-1153

7 Xiong $\mathrm{Y}$, Dong J, Huang ZQ, et al. Single-atom Rh/N-doped carbon electrocatalyst for formic acid oxidation. Nat Nanotechnol, 2020, 15: 390-397

8 Jiang J, Wieckowski A. Prospective direct formate fuel cell. Electrochem Commun, 2012, 18: 41-43

9 Hamnett A. Mechanism and electrocatalysis in the direct methanol fuel cell. Catal Today, 1997, 38: 445-457

10 Huang W, Wang H, Zhou J, et al. Highly active and durable me- thanol oxidation electrocatalyst based on the synergy of platinumnickel hydroxide-graphene. Nat Commun, 2015, 6: 10035

11 Zhang J, Li H, Ye J, et al. Sierpinski gasket-like Pt-Ag octahedral alloy nanocrystals with enhanced electrocatalytic activity and stability. Nano Energy, 2019, 61: 397-403

12 De Luna P, Hahn C, Higgins D, et al. What would it take for renewably powered electrosynthesis to displace petrochemical processes? Science, 2019, 364: eaav3506

13 Zhang W, Hu Y, Ma L, et al. Progress and perspective of electrocatalytic $\mathrm{CO}_{2}$ reduction for renewable carbonaceous fuels and chemicals. Adv Sci, 2018, 5: 1700275

14 Lim RJ, Xie M, Sk MA, et al. A review on the electrochemical reduction of $\mathrm{CO}_{2}$ in fuel cells, metal electrodes and molecular catalysts. Catal Today, 2014, 233: 169-180

15 Grozovski V, Climent V, Herrero E, et al. The role of the surface structure in the oxidation mechanism of methanol. J Electroanal Chem, 2011, 662: 43-51

16 Acres GJK, Frost JC, Hards GA, et al. Electrocatalysts for fuel cells. Catal Today, 1997, 38: 393-400

17 Qu Y, Gao Y, Kong F, et al. Pt-rGO-TiO 2 nanocomposite by UVphotoreduction method as promising electrocatalyst for methanol oxidation. Int J Hydrogen Energy, 2013, 38: 12310-12317

18 Feng Q, Zhao S, He D, et al. Strain engineering to enhance the electrooxidation performance of atomic-layer Pt on intermetallic $\mathrm{Pt}_{3} \mathrm{Ga}$. J Am Chem Soc, 2018, 140: 2773-2776

19 Huang J, Liu Y, Xu M, et al. PtCuNi tetrahedra catalysts with tailored surfaces for efficient alcohol oxidation. Nano Lett, 2019, 19: $5431-5436$

20 Xia BY, Wu HB, Li N, et al. One-pot synthesis of Pt-Co alloy nanowire assemblies with tunable composition and enhanced electrocatalytic properties. Angew Chem Int Ed, 2015, 54: 37973801

21 Watanabe $\mathrm{M}$, Zhu Y, Igarashi $\mathrm{H}$, et al. Mechanism of $\mathrm{CO}$ tolerance at Pt-alloy anode catalysts for polymer electrolyte fuel cells. Electrochemistry, 2000, 68: 244-251

$22 \mathrm{Xu} \mathrm{Y,} \mathrm{Cui} \mathrm{X,} \mathrm{Wei} \mathrm{S,} \mathrm{et} \mathrm{al.} \mathrm{Highly} \mathrm{active} \mathrm{zigzag-like} \mathrm{Pt-Zn} \mathrm{alloy}$ nanowires with high-index facets for alcohol electrooxidation. Nano Res, 2019, 12: 1173-1179

23 Igarashi H, Fujino T, Zhu Y, et al. CO tolerance of Pt alloy electrocatalysts for polymer electrolyte fuel cells and the detoxification mechanism. Phys Chem Chem Phys, 2001, 3: 306-314

24 Batista EA, Malpass GRP, Motheo AJ, et al. New insight into the pathways of methanol oxidation. Electrochem Commun, 2003, 5: 843-846

25 Cuesta A. At least three contiguous atoms are necessary for CO formation during methanol electrooxidation on platinum. J Am Chem Soc, 2006, 128: 13332-13333

26 Cuesta A. Electrooxidation of $\mathrm{C}_{1}$ organic molecules on Pt electrodes. Curr Opin Electrochem, 2017, 4: 32-38

27 Duchesne PN, Li ZY, Deming CP, et al. Golden single-atomic-site platinum electrocatalysts. Nat Mater, 2018, 17: 1033-1039

28 Saleem F, Ni B, Yong Y, et al. Ultra-small tetrametallic Pt-Pd-RhAg nanoframes with tunable behavior for direct formic acid/methanol oxidation. Small, 2016, 12: 5261-5268

29 Neurock M, Janik M, Wieckowski A. A first principles comparison of the mechanism and site requirements for the electrocatalytic oxidation of methanol and formic acid over Pt. Faraday Discuss, 2009, 140: 363-378

30 Yang S, Lee H. Atomically dispersed platinum on gold nanooctahedra with high catalytic activity on formic acid oxidation. 
ACS Catal, 2013, 3: 437-443

31 Zhang J, Sasaki K, Sutter E, et al. Stabilization of platinum oxygenreduction electrocatalysts using gold clusters. Science, 2007, 315 : $220-222$

32 Huang X, Zhao Z, Cao L, et al. High-performance transition metaldoped $\mathrm{Pt}_{3} \mathrm{Ni}$ octahedra for oxygen reduction reaction. Science, 2015, 348: 1230-1234

33 Beermann V, Gocyla M, Willinger E, et al. Rh-doped Pt-Ni octahedral nanoparticles: understanding the correlation between elemental distribution, oxygen reduction reaction, and shape stability. Nano Lett, 2016, 16: 1719-1725

34 Huang $\mathrm{H}$, Li K, Chen Z, et al. Achieving remarkable activity and durability toward oxygen reduction reaction based on ultrathin Rh-doped Pt nanowires. J Am Chem Soc, 2017, 139: 8152-8159

35 Li M, Zhao Z, Xia Z, et al. Lavender-like Ga-doped $\mathrm{Pt}_{3} \mathrm{Co}$ nanowires for highly stable and active electrocatalysis. ACS Catal, 2020, 10: 3018-3026

36 Wang W, Cao Z, Liu K, et al. Ligand-assisted, one-pot synthesis of Rh-on-Cu nanoscale sea urchins with high-density interfaces for boosting CO oxidation. Nano Lett, 2017, 17: 7613-7619

37 Guo DJ, Ding Y. Porous nanostructured metals for electrocatalysis. Electroanalysis, 2012, 24: 2035-2043

38 Ji Y, Wu Y, Zhao G, et al. Porous bimetallic Pt-Fe nanocatalysts for highly efficient hydrogenation of acetone. Nano Res, 2015, 8: 2706-2713

39 Jiang B, Li C, Malgras V, et al. Mesoporous Pt nanospheres with designed pore surface as highly active electrocatalyst. Chem Sci, 2016, 7: 1575-1581

40 Inzelt G. Inorganic Chemistry. In: Bard AJ, Stratmann M, Scholz F, Pickett $\mathrm{CH}$ (eds). Encyclopedia of Electrochemistry. Weinhein: Wiley-VCH, 2006, 7: 39-41

41 Fu GT, Xia BY, Ma RG, et al. Trimetallic PtAgCu@PtCu core@ shell concave nanooctahedrons with enhanced activity for formic acid oxidation reaction. Nano Energy, 2015, 12: 824-832

42 Chen YX, Miki A, Ye S, et al. Formate, an active intermediate for direct oxidation of methanol on Pt electrode. J Am Chem Soc, 2003, 125: 3680-3681

43 Liu HX, Tian N, Brandon MP, et al. Tetrahexahedral Pt nanocrystal catalysts decorated with $\mathrm{Ru}$ adatoms and their enhanced activity in methanol electrooxidation. ACS Catal, 2012, 2: 708-715

44 Wang W, Chen X, Zhang X, et al. Quatermetallic Pt-based ultrathin nanowires intensified by $\mathrm{Rh}$ enable highly active and robust electrocatalysts for methanol oxidation. Nano Energy, 2020, 71: 104623

45 Kunimatsu K, Golden WG, Seki H, et al. Carbon monoxide adsorption on a platinum electrode studied by polarization modulated FT-IRRAS. 1. Carbon monoxide adsorbed in the double-layer potential region and its oxidation in acids. Langmuir, 1985, 1: 245-250

46 Chang J, Feng L, Jiang K, et al. Pt-CoP/C as an alternative PtRu/C catalyst for direct methanol fuel cells. J Mater Chem A, 2016, 4: 18607-18613

47 Inukai J, Ito M. Electrodeposition processes of palladium and rhodium monolayers on $\mathrm{Pt}(111)$ and $\mathrm{Pt}(100)$ electrodes studied by IR reflection absorption spectroscopy. J Electroanal Chem, 1993, 358: 307-315

48 Gómez R, Rodes A, Pérez JM, Feliu JM, Aldaz A, Electrochemical and in situ FTIR studies of the CO adsorption at palladium and rhodium multilayers deposited on platinum single crystal surfaces. I. Pt(110) substrate. Surf Sci, 1995, 327: 202-215

49 Gómez R, Feliu JM. Rhodium adlayers on Pt(111) monocrystalline surfaces. Electrochemical behavior and electrocatalysis. Electrochim Acta, 1998, 44: 1191-1205

50 Sheng T, Sun SG. Insight into the promoting role of $\mathrm{Rh}$ doped on $\mathrm{Pt}(111)$ in methanol electro-oxidation. J Electroanal Chem, 2016, 781: 24-29

Acknowledgements This work was supported by the National Natural Science Foundation of China (21771067), the Natural Science Foundation of Fujian Province (2017J06005 and 2019J01058), the Program for New Century Excellent Talents in Fujian Province University, the Promotion Program for Young and Middle-aged Teacher in Science and Technology Research of Huaqiao University (ZQN-PY507), and the Scientific Research Funds of Huaqiao University. We also thank the Instrumental Analysis Center of Huaqiao University for the analysis support.

Author contributions Xie S and Wang W designed the experiments and analyzed most of the data. Wang W, Chen X, Zhang Y, Han Y, Chen $\mathrm{X}$ and Liu $\mathrm{K}$ conducted the material synthesis, structural characterizations and catalytic tests. Ye J and Wang $\mathrm{W}$ conducted the in situ FTIR tests and analyzed the results. Wang W, Chen X and Xie S wrote the manuscript. All authors contributed to the discussion about the results and the manuscript.

Conflict of interest The authors declare that they have no conflict of interest.

Supplementary information Supplementary materials are available in the online version of the paper.

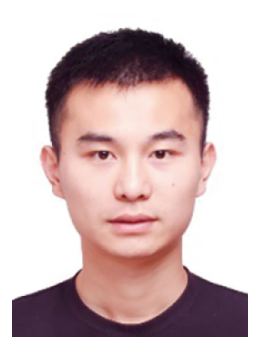

Wei Wang received his BS degree in chemical engineering from Qingdao University of Science and Technology in 2015, and MS degree in physics from Xiamen University under the supervision of Prof. Shuifen Xie in 2018. From Aug. 2018 to Jul. 2019, he worked as a research assistant at Huaqiao University with Prof. Shuifen Xie. $\mathrm{He}$ is currently a $\mathrm{PhD}$ candidate at the $\mathrm{Na}$ tional University of Singapore. His research interests include the study of inorganic nanocatalysts.

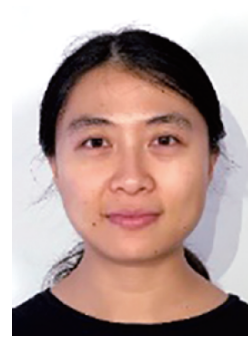

Xuejiao Chen received her BS in 2007 from Southwest University and $\mathrm{PhD}$ in physical chemistry in 2013 from Wuhan University. She worked as a postdoctoral fellow in Professor Zhong-Qun Tian's Group at Xiamen University from 2013 to 2017. She has been an assistant professor at Huaqiao University (Xiamen Campus) since 2017. Her research interests mainly focus on the in situ vibrational spectroscopic study at the electrochemical interfaces. 


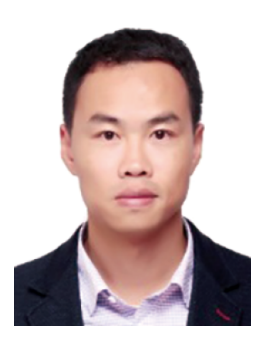

Shuifen Xie received his BS degree in chemistry (2007) and PhD degree in physical chemistry (2013) from Xiamen University, under the supervision of Prof. Zhaoxiong Xie. From Sep. 2011 to Aug. 2013, he worked as a visiting scholar at Georgia Institute of Technology with Prof. Younan Xia. He is currently a full professor at the College of Materials Science and Engineering, Huaqiao University. His research interests focus on inorganic nanomaterials for catalytic applications and energy storage/conversion.
原位表面掺杂增强PtNiCoRh纳米晶对 $\mathrm{C}_{1}$ 燃料电 氧化的催化性能

王伟 ${ }^{13 \dagger}$, 陈雪皎 ${ }^{1 \dagger}$, 叶进裕 ${ }^{2}$, 张玉辉 ${ }^{1}$, 韩艳晨 ${ }^{1}$, 陈孝为 ${ }^{1}$, 刘凯 ${ }^{1}$, 谢水奋 ${ }^{1 *}$

摘要 异质原子掺杂的铂基纳米晶在多相催化领域具有广阔的应 用前景, 然而基于原位表面掺杂策略来优化表面原子构型仍颇具 挑战. 本研究通过原位表面掺杂的化学方法制备出多枝状PtNi$\mathrm{CoRh}$ 四元金属纳米晶. 抗坏血酸和铑离子的配位作用实现了铑离 子的延迟还原, 从而可控地将铑原子针定在催化剂表面层. 电催化 研究表明原位表面掺杂的 $\mathrm{Pt}_{67} \mathrm{Ni}_{16} \mathrm{Co}_{16} \mathrm{Rh}_{1}$ 纳米晶针对甲醇、甲醛 和甲酸电氧化都具有优异的催化活性、稳定性及抗CO中毒特性. 原位电化学红外光谱结果表明抗腐蚀性强的铑原子的表面掺杂能 有效调控催化剂表面Pt位点, 其中CO中毒中间体以更容易氧化消 除的桥位态吸附在Rh-Pt异质位点. 本研究提出的原位表面掺杂策 略将有助于设计高原子利用率的高效多相催化剂. 